\title{
Antibacterial activities of Calpurnia aurea and Ocimum lamiifolium extracts against selected gram positive and gram-negative bacteria
}

\author{
Addis Melese ${ }^{1}$, Beyene Dobo ${ }^{1, *}$, Abriham Mikru ${ }^{1}$ \\ ${ }^{1}$ Hawassa University, Department of Biology, PO Box 05, Hawassa, Ethiopia.
}

\begin{abstract}
Indigenous knowledge, literature reports and ethnobotanical records suggest that plants are the basis for medicines. This study was designed to examine in-vitro antibacterial activity of Calpurnia aurea (leaf, bark) and Ocimum lamiifolium (leaf, flower) collected from Wonsho and Shebedino districts of Sidama Zone, southern Ethiopia, with different solvents against three Gram negative (Escherichia coli, Salmonella typhimurium and Pseudomonas aeruginosa) and one Gram positive (Staphylococcus aureus) bacteria in 2018. The leaf and bark of Calpurnia aurea and leaf and flower of Ocimum lamiifolium were dried, powdered and extracted with $80 \%$ acetone, ethanol, methanol and distilled water. Disc diffusion method was used for the antibacterial assay and measuring the zone of inhibition and minimum inhibition concentration (MIC) was determined by broth macrodilution method. The highest percentage yield of crude bioactive agents, i.e., $36.9 \%$ was obtained from Ocimum lamiifolium leaf with methanol as a solvent, while the lowest yield $12.6 \%$ was obtained from Calpurnia aurea bark with acetone extract. All crude extracts from the different plant parts showed antibacterial activity. Accordingly, Calpurnia aurea bark with methanol extract exhibited the highest antibacterial activity $22.64 \pm 0.95(\mathrm{~mm})$ against $S$. aureus which was comparable to standard antibiotic disc Ciprofloxacin with inhibition zone of $24.00 \pm 0.19(\mathrm{~mm})$, while the lowest inhibition of $6.12 \pm 0.41(\mathrm{~mm})$ was recorded from Ocimum lamiifolium flower with water crude extract against $P$. aeruginosa. The MIC of $3.13 \mathrm{mg} / \mathrm{ml}$ was observed from methanol crude extract of bark of Calpurina aurea on $S$. aurea. Crude bark extract of Methanol showed the highest antibacterial activity. The studies revealed that antibacterial activity of the crude extracts from the different parts of the plant were variable when extracted by different solvents, however, possesses good antimicrobial activity which support the traditional use of the plant in the treatment of bacterial infections under study. Finally, to support the traditional users, scientific verification on phytochemical analysis and toxicity test should be carried out to confirm users' safety.
\end{abstract}

Key words: Antibacterial activity, Disc diffusion, MIC, Plant crude extract, Zone of inhibition

DOI: https://dx.doi.org/10.4314/ejst.v12i3.2

${ }^{*}$ Corresponding author: beyeneashl@yahoo.co.uk 


\section{INTRODUCTION}

Medicinal Plants are important antimicrobial agents used in different parts of the world. Plant based traditional medicine plays an essential role in human and animal medication and a significant number of world population rely on traditional medicines for their primary health care (Owolabi et al., 2007). Many communities in Asia, Africa and South America used medicinal plants for the treatment of diseases for centuries. In spite of the great advances achieved in modern medicine, thousands of rural communities in developing countries still depend on folklore medicine to cure diseases mainly because of economic and cultural factors (Kamatenesi and Oryem-Origa, 2007).

However, such plants should be investigated for better understanding of their properties, safety and efficacy to develop antimicrobial drugs (Khulbe and Sati, 2009). Accordingly, the utilization of plants for the production of natural compounds of commercial interest draws increasing attention over the past decades (Canter et al., 2005). Furthermore, the emergence of microbial drug resistance and limited therapeutic efficacy of many of the available drugs necessitated search for potent antibacterial drugs with new modes of action. Local medicinal plants are potential source of novel antimicrobial agents and anti-Quorum sensing substances (Bacha et al., 2016). According to Abebe Dawit (2011), traditional remedies are the most important and sometimes the only source of therapeutics for nearly $80 \%$ of the population and $95 \%$ of traditional medicinal preparations in Ethiopia.

Ethiopia is a country known for its rich plant biodiversity and traditional use of plant-based drugs for curing or treating of many human and animal diseases. In Ethiopia alone, 1000 plant species are estimated to be in use for traditional medication (Tesema et al., 2002). WHO estimated that the majority of the population in developing countries, including $90 \%$ of African population, rely on traditional medicinal plants for their healthcare (WHO, 2011). Today, infectious diseases are responsible for mortality (particularly in third-world countries), and worse, synthetic (artificial) antibiotics are expensive. The increasing global trend of resistance to drugs among Gram-positive and Gram-negative bacteria poses major challenges (Bassetti et al., 2011). Multidrug resistant bacteria are resistant to several different antibiotics. The management of multi-drug resistant bacterial strains are difficult because treatment options are limited and beyond the reach of healthcare systems (Miyakis et al., 2011). Therefore, there is urgent need to explore new effective drugs for the treatment of infectious diseases (Aiyegoro et al., 2011). Plant products and their active constituents play an important role in plant disease control by combating growth and development of pathogens. Plant based natural constituents can be derived from any part of the plant like bark, leaves, flowers, roots, fruits, seeds, etc. (Gordon and David, 2001). These plant products possess 
various secondary metabolites with significant inhibitory effect against the growth of pathogens; hence, the plant and their products should be utilized to combat disease causing pathogens. Antimicrobial research is geared towards the discovery and development of novel antibacterial and antifungal agents.

Ocimum lamifolium is an important medicinal herb belonging to family Lamiaceae. It is an indigenous plant in Ethiopia, locally called "dama-kassie" (in Amharic) and is one of the most common traditional medicinal plants used in Ethiopia (Mirutse et al., 2010). Ocimum lamiifolium extracts are also known to have antibacterial, antifungal, insect repellent (Ermiyas Dagne, 2009), and antiinflammatory activities in humans (Kashyap et al., 2011).

Calpurnia aurea is a plant within the family of Fabaceae. It is widely distributed in Ethiopia with a local name "digita" in Amharic and used in traditional medicine to treat diverse medical conditions in humans and animals (Zorloni, 2007). Abdella et al. (2013) reported that all parts of the plant are used for different human and animal diseases. Tadeg et al. (2005) have also reported that different parts of Calpurina aurea are used to treat different diseases such as diarrhea, stomach-ache, bowel, and bladder disorders. All these tell us that a range of medicinal plants with antimicrobial properties have been widely used by traditional healers. However, therapeutic potentials of some of these medicines have not been scientifically evaluated (Havagiray et al., 2004). Therefore, it is necessary to establish the scientific basis for the therapeutic actions of traditional plant medicines as these may serve as the source for the development of more effective drugs. The aim of the present study was, therefore, to evaluate the possible antimicrobial (in vitro) properties of the leaf and bark extract of $C$. aurea and leaf and flower of $O$. lamiifolium against four pathogenic bacterial strains (Escherichia coli, Staphylococcus aureus, Salmonella typhimurium and Pseudomonas aeruginosa).

\section{MATERIALS AND METHODS}

\section{Description of study area}

The study medicinal plants were collected from Boricha and Dale Woreda (District) of Sidama zone, southern Ethiopia. Sidama administrative Zone is found in Southern Nations Nationalities and Peoples Regional State (SNNPR), located 313 $\mathrm{km}$ away from Addis Ababa. It is located in the north eastern part of the region and bounded by Oromiya in the North, east and south east, with Gedieo Zone in the South, and Wolayta Zone in the West. Its geographic location lies between $6^{\circ} 14^{\prime}$ and $7^{\circ} 18^{\prime}$ North latitude and $37^{\circ} 92^{\prime}$ and $39^{\circ} 14^{\prime}$ East longitude. Total area of the 
Sidama Administrative Zone is about $6981.8 \mathrm{~km}^{2}$. The mean annual temperature is $19.5^{\circ} \mathrm{C}$. With 19 woredas and 4 administrative towns, it is one of the densely populated zones in the region (CSA, 2013; Sidama Zone FEDD Abstract, 2014).

\section{Collection and authentication of plant material}

Fresh leaf and barks of Calpurnia aurea, and also flowers and leaf of Ocimum lamiifolium were collected from randomly selected kebeles of Boricha district (Arossa and Galakohireye) and Dale district (Ferro I and Ferro II) of Sidama during the months of September and October 2018 and the identity of each plant specimen was confirmed at the National Herbarium, Addis Ababa University. Parts of plant separately collected were transported in plastic bags to the laboratory for further processing. In the laboratory the samples were washed under running tap water to remove dust particles and followed by final rinsing with distilled water. They were then placed on clean plastic plates and air dried at room temperature until their weight became constant. Then the dried samples were grounded to fine powder using electric grinder (FM100 model, China) and stored in sterile bottle at $4{ }^{\circ} \mathrm{C}$ for analysis of disc diffusion and MIC against test bacteria (Handa et al., 2008).

\section{Preparation of plant extracts}

The extracts of leaf and bark of Calpurnia aurea, and leaf and flower of Ocimum lamiifolium were prepared by dissolving $10 \mathrm{~g}$ of each fine plant powder separately in $100 \mathrm{~mL}$ of $80 \%$ of acetone, $(80 \%)$ methanol, $(80 \%)$ ethanol and water (CSLI, 2012). The extracts were prepared in $250 \mathrm{ml}$ capacity conical flask by soaking 10 $\mathrm{g}$ of each plant powder separately in $100 \mathrm{ml}$ of each solvent, methanol, ethanol, acetone and water for 3 days (hand-shaken several-to-many times a day) until the soluble material dissolved. Thereafter, each extract was filtered using Whatman no. 1 filter paper and the filtrate was dried in oven with rotary fan at $40{ }^{\circ} \mathrm{C}$ until the solvent from extracts further evaporated. The resulting extracts were packed into a vial and stored at $20{ }^{\circ} \mathrm{C}$ until further investigation (Sukhdev et al., 2008).

\section{Determination of extraction yield}

The percentage yield of each extract was obtained using the formula

Percent extracts $=\underline{\mathrm{W}_{2}} \underline{\mathrm{W}}_{0} \underline{\mathrm{W}_{1}} \times 100$

Where, $\mathrm{W}_{2}$ is the weight of the dried extract and the container, $\mathrm{W}_{1}$ the weight of the container alone and $\mathrm{W}_{0}$ the weight of the dried plant material (Anokwuru et al., 2011).

\section{Test organisms}

The test bacteria one gram positive (Staphylococcus aureus) and three gram negative (Escherichia coli, Pseudomonas aeruginosa and Salmonella 
typhimurium), all clinical isolates were obtained from Ethiopian Public Health Institute (EPHI), Addis Ababa, Ethiopia. The test bacteria were cultured on nutrient agar and stored at $4{ }^{\circ} \mathrm{C}$ until use (CLSI, 2012).

\section{Preparation of media}

The medium was prepared according to the manufacturer's instructions. $38 \mathrm{~g}$ Mueller Hinton Agar was added to a flask containing $1000 \mathrm{ml}$ of distilled water and gently heated until the medium is completely dissolved. The medium was sterilized by autoclaving at $121{ }^{\circ} \mathrm{C}$ for 15 minutes. After cooling to about $50{ }^{\circ} \mathrm{C}$, approximately $25 \mathrm{ml}$ of the sterilized medium was aseptically poured into $90 \mathrm{~mm}$ diameter sterilized Petri-dishes and allowed to dry until the excess moisture from the surface of the agar was removed before use. The sterility of the prepared media was checked by incubation of randomly selected plates at $37^{\circ} \mathrm{C}$ for $24 \mathrm{~h}$ (CLSI, 2012).

\section{Preparation of inocula}

This method assesses the antimicrobial activity of a bioactive compound by culturing bacteria in the presence of the compound/extract and measuring the zone of inhibition which corresponds to the area where no bacterial growth is observed under optimum conditions for bacterial growth. The higher the diameter (zone of inhibition) the more susceptible will be the bacteria to the bioactive compounds/extracts of the plant.

The method was executed according to the procedures described before (CLSI, 2012). Accordingly, three to five colonies from pure cultures of each of the four selected bacterial species were transferred with the help of a sterile wire loop into a separately labeled test tube containing $5 \mathrm{ml}$ of nutrient broth and incubated to grow at a temperature of $37{ }^{\circ} \mathrm{C}$ for two hours. The prepared culture was standardized to $0.5 \mathrm{McF}$ arland turbidity standards using the spectrophotometer (optical density of 1.0 at $625 \mathrm{~nm}$ ) by adding sterile nutrient broth to obtain the desired cell density of $1.5 \times 10^{8}($ cells $/ \mathrm{ml})$. The $0.5 \mathrm{McF}$ arland turbidity standard was prepared by adding $0.5 \mathrm{ml}$ of $0.048 \mathrm{M} \mathrm{BaCl}_{2}\left(1.17 \% \mathrm{w} / \mathrm{v} \mathrm{BaCl} 2.2 \mathrm{H}_{2} \mathrm{O}\right)$ to 99.5 $\mathrm{ml}$ of $0.18 \mathrm{M} \mathrm{H}_{2} \mathrm{SO}_{4}(1 \% \mathrm{v} / \mathrm{v} 0.05 \mathrm{ml}$ of $1.175 \%$ of barium chloride dihydrate $\left(\mathrm{BaCl}_{2} \cdot 2 \mathrm{H}_{2} \mathrm{O}\right)$, with $9.95 \mathrm{~mL}$ of $1 \%$ sulphuric acid $\left(\mathrm{H}_{2} \mathrm{SO}_{4}\right)$.

\section{Preparation of Disc}

Diffusion discs of $6 \mathrm{~mm}$ diameter were prepared from absorbent filter paper (Whatman no.1) by using a paper Puncher and sterilized at $120{ }^{\circ} \mathrm{C}$ for $1 \mathrm{~h}$ and dried in an oven. Then after, sterilized discs were soaked aseptically by applying $30 \mu \mathrm{l}$ of each crude extract of plant at a concentration of $100 \mathrm{mg} / \mathrm{ml}$ using sterile digital 
micropipette and then allowed to dry at a room temperature for 15 minutes and then placed in sterile container and stored at $4{ }^{\circ} \mathrm{C}$ until further use (CLSI, 2012).

\section{Disc diffusion test}

The disc diffusion technique has been widely used to assay plant extract for antimicrobial activity (Taiwo et al., 2007). A sterile cotton swabs were dipped into the adjusted standardized broth inoculums suspension by rotating the swab. The swab was then evenly streaked over the entire surface of Muller Hinton agar plate. Streaking was repeated by rotating the plate approximately $60^{\circ}$ each time to ensure an even distribution of inoculum. After inoculation, for each test bacterium, sterilized discs which were soaked under $30 \mu \mathrm{l}$ of each crude extract of plant at a concentration of $100 \mathrm{mg} / \mathrm{ml}$ were applied while sterile, blank paper discs were soaked by each solvent (ethanol, methanol, acetone and water served as negative control), standard antibiotic ciprofloxacin disc $30 \mu \mathrm{g} / \mathrm{disc}$ was used as positive control.

Finally, the disc was applied on the inoculated $90 \mathrm{~mm}$ plates using flame sterilized forceps approximately equidistance to each other. Finally, all the plates were incubated at $37^{\circ} \mathrm{C}$ for 24 hours. The antibacterial activities of the plant extracts were evaluated by measuring the diameter of the inhibition zone in each of the plates at the end of the incubation period. The diameter of the inhibition zone, including the diameter of the disc was measured by using sliding digital micro caliper. The bacterial activity of the crude extracts on the test bacteria were compared with those of the negative and positive controls according to CLSI (2012).

\section{Minimum Inhibition Concentration (MIC)}

The minimum inhibitory concentration is defined as the lowest concentration which can inhibit any visible bacterial growth on the culture plates (Radojevic et al., 2012). In this study Broth macro dilution assay were used. For each plant extract, a stock solution of $200 \mathrm{mg} / \mathrm{ml}$ was prepared. A $10 \mathrm{ml}$ of Muller Hinton broth was added into each sterilized test tubes. From a stock solution, a double dilution method to bring $100 \mathrm{mg} / \mathrm{ml}, 50 \mathrm{mg} / \mathrm{ml}, 25 \mathrm{mg} / \mathrm{ml}, 12.5 \mathrm{mg} / \mathrm{ml}, 6.25 \mathrm{mg} / \mathrm{ml}$, $3.125 \mathrm{mg} / \mathrm{ml}$ and $1.56 \mathrm{mg} / \mathrm{ml}$ ) were performed by using sterile digital micropipette (CLSI, 2012). Finally, $20 \mu \mathrm{l}$ standard suspension of the test organism (which is adjusted to $0.5 \mathrm{McF}$ arland standards) was added to each tube. Mixed by gently shaking the tubes and incubated the tubes at $37^{\circ} \mathrm{C}$ for $24 \mathrm{~h}$. After $24 \mathrm{~h}$ incubation, the solution was further inoculated in agar plates. MIC was taken as the highest dilution of the extract that inhibited the growth of the bacteria. The lowest concentrations of the extracts, which inhibited the bacterial growth after a period of $24 \mathrm{~h}$ of incubation at $37^{\circ} \mathrm{C}$, were recorded as MIC. Broth inoculated with test organism without extract solution was used as a positive control and only broth was used as a negative control. All testes were done in triplicates (CLSI, 2012). 


\section{Data analysis}

For each assay, all the measurements were triplicate and the results were presented as mean $\pm \mathrm{SD}$. The statistical analyses were performed using two-way ANOVA. Then Duncan's test was used to compare means of antibacterial activity as compared to extraction solvents, plant parts and the difference in the sensitivity of the test microorganisms using the statistical package for social Sciences (SPSS) version 20 and $\mathrm{P}$-values $<0.05$ were considered as statistically significant.

\section{RESULTS AND DISCISIONS}

\section{Percent extract yield}

In this study the highest amount of extraction yield (31.9\%) was obtained from $80 \%$ methanol extract of Ocimum lamiifolium leaf, followed by $30.4 \%$ from water extract of Calpurnia aurea leaf and 30.1\% from Ocimum lamiifolium flower with $80 \%$ ethanol as a solvent, while the lowest (12.6\%) was obtained from $80 \%$ acetone extract of Calpurnia aurea bark (Table 1).

Table 1. Percent extract yield of Calpurnia aurea and Ocimum lamiifolium extracted using different solvents

\begin{tabular}{lllr}
\hline Plant type & Parts used & Extraction type & \% yield (w/w) \\
\hline Calpurnia aurea & Leaf & Water & 30.4 \\
& & Acetone & 28.5 \\
& & Ethanol & 20.2 \\
& & Methanol & 26.2 \\
& \multirow{3}{*}{ Bark } & Water & 16.0 \\
& & Acetone & 12.6 \\
& & Ethanol & 19.0 \\
& & Methanol & 21.0 \\
Ocimum lamiifolium & Leaf & Water & 22.3 \\
& & Acetone & 15.7 \\
& & Ethanol & 21.5 \\
& & Methanol & 31.9 \\
& \multirow{3}{*}{ flower } & Water & 23.5 \\
& & Acetone & 17.3 \\
& & Ethanol & 30.1 \\
& & Methanol & 24.2 \\
\hline
\end{tabular}

The highest amount of extraction yield (31.9\%) was obtained from Ocimum lamiifolium leaf from $80 \%$ methanol followed by water $(22.3 \%)$ and $80 \%$ ethanol (21.5\%). This result showed better yield than that reported by Amare et al. (2013) on $80 \%$ ethanol $(9.4 \%)$ and water $(10.7 \%)$ crude extract. The lowest extraction 
yield (15.6\%) was observed from Ocimum lamiifolium leaf from $80 \%$ acetone solvent. The highest yield (30.1\%) observed in the case of Ocimum lamiifolium flower with $80 \%$ ethanol was followed by $24.2 \%$ with $80 \%$ methanol and $23.5 \%$ with water extract. The lowest (17.32\%) extract yield was observed from Ocimum lamiifolium flower with $80 \%$ acetone as a solvent.

Regarding Caplurnia aurea leaf the highest extraction yield (30.4\%) observed from water extract was followed by $(28.5 \%)$ from $80 \%$ acetone and $(26.2 \%)$ from $80 \%$ methanol as extraction solvent. A comparable result (29.5\%) was observed by Hailu et al. (2005) with $80 \%$ methanol extract of Calpurnia aurea leaf. In the case of Calpurnia aurea bark the maximum yield (21\%) extracted from $80 \%$ methanol was followed by $19 \%$ extracted with $80 \%$ ethanol. The lowest extract yield (12.6\%) was observed with $80 \%$ acetone extraction solvent.

This study showed solvent with varying polarity had a significant effect on the extraction capacity. Selecting appropriate extraction solvent is crucial in the extraction process. Different solvents have different extraction capacities and spectrum of solubility for phyto-constituents (Srinivasan et al., 2001). These bioactive compounds are maximally extracted in more polar solvents (Chenielle et al., 2009; Perumal et al., 2012). The addition of $20 \%$ water to $80 \%$ methanol, ethanol and acetone has enhanced the antimicrobial activity of the extract. Thus, the selective extraction of bioactive molecules from natural sources by appropriate solvents is important for obtaining compounds with high biological activities which can be used as preservative ingredients in the pharmaceutical industry (Perumal et al., 2012).

\section{Antibacterial Assay}

The antibacterial assay of the crude extract of all tested plant parts are shown in Table 2. The highest zone of inhibition were observed among all tested plant part on methanol crude extract of Calpurnia aurea bark $(22.64 \pm 0.95 \mathrm{~mm})$ against $S$. aureus followed by methanol crude extract $(19.18 \pm 0.66 \mathrm{~mm})$ of the bark against $E$. coli and ethanol crude extract of Calpurnia aurea bark $(17.49 \pm 2.56 \mathrm{~mm})$ against $S$. typhimurium, while the least zone of inhibition was observed from Ocimum lamiifolium flower with water crude extract $6.12 \pm 0.41 \mathrm{~mm}$ ) against $P$. aeruginosa (Table 2).

The results of the antibacterial assay of the crude extract of Calpurnia aurea leaf with four different solvents showed zone of inhibition against all tested bacteria. The highest zone of inhibition $(14.59 \pm 0.72 \mathrm{~mm})$ was observed with methanol extract against $E$. coli which was significantly different $(\mathrm{P}<0.05)$ from ethanol $(11.24 \pm 1.18 \mathrm{~mm})$ and water $(10.63 \pm 0.85 \mathrm{~mm})$ crude extracts against $E$. coli. The methanol crude extract of Calpurnia aurea leaf showed zone of inhibition of $13.86 \pm 0.33 \mathrm{~mm}$ against $S$. aureus and not significantly different $(\mathrm{P}>0.05)$ with 
acetone crude extract $(12.4 \pm 1.69 \mathrm{~mm})$. The highest zone of inhibition $(9.57 \pm 0.68$ $\mathrm{mm}$ ) was recorded against $S$. typhimurium with ethanol crude extract of Calpurnia aurea leaf. Also, methanol extract of Calpurina aurea leaf showed highest zone of inhibition $(9.52 \pm 0.4 \mathrm{~mm})$ against $P$. aeruginosa. This study demonstrated a comparable result with the findings obtained by Shemsu et al. (2013), which recorded inhibition zone of the methanol extract of Calpurnia aurea leaf to be 14 $\mathrm{mm}$ against $E$. coli, followed by $11 \mathrm{~mm}$ against $S$. aurea, $9 \mathrm{~mm}$ against $S$. typhimurium and $9 \mathrm{~mm}$ against $P$. aerugenosa.

In agreement to the current study, Binyam et al. (2014) reported high antibacterial activity $(13.3 \mathrm{~mm})$ against $E$. coli and $(8.6 \mathrm{~mm})$ against $S$. typhimurium with methanol extract of leaf of Calpurnia aurea. Acetone crude extract of Calpurnia aurea leaf showed the highest zone of inhibition $(13.47 \pm 2.01 \mathrm{~mm})$ against $E$. coli and $12.4 \pm 1.69 \mathrm{~mm}$ against $S$. aureus which was better antibacterial activity than ethanol crude extract $(11.24 \mathrm{~mm})$ against $E$. coli and $9.27 \mathrm{~mm}$ against $S$. typhimurium. The least zone of inhibition $(6.82 \pm 0.92 \mathrm{~mm})$ regarding Calpurnia aurea leaf was observed with water extract against $S$. typhimurium.

The methanol extract of Calpurnia aurea bark showed the high zone of inhibition $(22.64 \pm 0.95 \mathrm{~mm})$ against $S$. aureus which was comparable to that of the standard antibiotic Ciprofloxacin $(24.00 \pm 0.19 \mathrm{~mm})$, and was significantly different $(\mathrm{P}<0.05)$ with acetone $(17.4 \pm 1.46 \mathrm{~mm})$, ethanol $(13.67 \pm 0.83 \mathrm{~mm})$ and water $(10.54 \pm 0.54 \mathrm{~mm})$ crude extract of Calpurnia aurea bark against $S$. aureus. Also, methanol extract of Calpurnia aurea showed high zone of inhibition against $E$. coli $(19.18 \pm 0.66 \mathrm{~mm})$ which was significantly different $(\mathrm{P}<0.05)$ with ethanol $(16.71 \pm 0.89 \mathrm{~mm})$, acetone $(15.53 \pm 0.27 \mathrm{~mm})$ and water $(7.29 \pm 1.61 \mathrm{~mm})$ crude extract of Calpurnia aurea bark against E. coli. The ethanol extract of Calpurnia aurea bark showed the high zone of inhibition $(17.49 \pm 2.56 \mathrm{~mm})$ against $S$. typhimurium, and not significantly different $(\mathrm{P}>0.05)$ with methanol $(16.13 \pm 1.67$ $\mathrm{mm})$ but they were significantly different $(\mathrm{P}<0.05)$ from acetone $(11.82 \pm 1.19 \mathrm{~mm})$ and water $(8.61 \pm 1.1 \mathrm{~mm})$ crude extract of Calpurnia aurea against $S$. typhimurium. The ethanol extract of Calpurnia aurea bark showed the high zone of inhibition $(11.95 \pm 1.1 \mathrm{~mm})$ against $P$. aeruginosa, which was not significantly different from methanol crude extract $(11.78 \pm 1.01 \mathrm{~mm})$ and acetone $(10.04 \pm 1.57 \mathrm{~mm})$ crude extract of Calpurnia aurea bark against $P$. aeruginosa.

The current results of the methanol crude extract of Ocimum lamiifolium leaf showed antibacterial activity against all tested bacteria; on E. coli $(14.7 \pm 2.39 \mathrm{~mm})$ followed by $(13.2 \pm 1.49 \mathrm{~mm})$ against $S$. aureus $(11.84 \pm 0.74 \mathrm{~mm})$ against $S$. typhimurium and $(10.63 \pm 0.54 \mathrm{~mm})$ against $P$. aeruginosa. In contrast, methanol extract of Ocimum lamiifolium didn't show any zone of inhibition against $P$. 
aeruginosa (Teklit Gebregiorgis Amabye and Said Mussa, 2015) but in this study $P$. aeruginosa had zone of inhibition of $10.63 \pm 0.54 \mathrm{~mm}$. This variation might be due to extraction solvent.

In this study ethanol and water crude extract of Ocimum lamiifolium leaf had antibacterial activity against $E$. coli, S.aureus and $P$. aeruginosa. Similarly, ethanol crude extract showed antibacterial activity against $E$. coli $(13.5 \mathrm{~mm})$ and against $S$. aureus $(12 \mathrm{~mm})$ and also water crude extract of Ocimum lamiifolium against $E$. coli $(15.5 \mathrm{~mm}), S$. aureus $(13.5 \mathrm{~mm})$ and $P$. aeruginosa $(13 \mathrm{~mm})$ (Amare et al., 2013).

The methanol extract of Ocimim lamiifolium flower showed the highest zone of inhibition $(13.91 \pm 2.2 \mathrm{~mm})$ on $E$. coli. The next highest $(12.85 \pm 0.64 \mathrm{~mm})$ was recorded for methanol crude extract against $S$. aureus. Zone of inhibition recorded for methanol extract against $S$. typhimurium and $P$. aeruginosa were $10.39 \pm 0.83$ $\mathrm{mm}$ and $9.42 \pm 0.76 \mathrm{~mm}$, respectively. The difference in zone of inhibition among the four tested bacteria depends on the extraction solvent, the bacteria inheritance behavior and the plant parts (Bhumika and Bijal, 2015).

The positive and negative controls were also carried out to monitor antimicrobial activity of the medicinal plants. Standard antibiotics Ciprofloxacin was taken as positive control. All tested bacteria were highly susceptible to standard antibiotic with different zone of inhibition for different microorganisms; in $E$. coli $(26.15 \pm 0.38 \mathrm{~mm}), S$. aureus $(24.00 \pm 0.19 \mathrm{~mm})$, P. aeruginosa $(27.70 \pm 0.45 \mathrm{~mm})$ and S. typhimurium $(26.83 \pm 0.27 \mathrm{~mm})$. Also, a comparable result was recorded from the methanol crude extract of Calpurnia aurea bark to standard antibiotic against S. aureus. All negative controls didn't show any antibacterial activities (Table 2).

In the current study there was a significant difference $(p<0.05)$ in antibacterial activities among the crude extracts of the two plant parts of Calpurnia aurea (leaf and bark) depend on the extraction solvents against all tested bacteria. Comparing the mean inhibition zone of Calpurnia aurea bark, the crude extracts from bark with methanol as a solvent showed the highest inhibition zone $(17.19 \mathrm{~mm})$ against all tested bacteria and significantly different $(P<0.05)$ from the three solvents.

The crude extract from the bark of Calpurnia aurea showed mean inhibition zone $(14.12 \mathrm{~mm})$ with ethanol extract and $13.70 \mathrm{~mm}$ with acetone extract had a better antibacterial activity and also had a significant difference $(\mathrm{P}<0.05)$ among them. The lowest antibacterial activity $(8.90 \mathrm{~mm})$ was recorded from the crude extract of Calpurnia aurea barks with water as a solvent. This indicated that the release of bioactive compounds on plant part depend on extraction solvent against all tested bacteria and comparing among Calpurnia aurea bark with different solvents, the methanol extract of Calpurnia aurea bark was effective to treat those tested bacteria (Table 3 ). 
Table 2. (Mean $\pm \mathrm{SD})$ of antibacterial activities of leaf and bark of Calpurnia aurea and leaf and flower of Ocimum lamiifolium crude extracts obtained using different solvents against four bacterial species.

\begin{tabular}{|c|c|c|c|c|c|}
\hline \multirow[b]{2}{*}{ Plant Part } & \multirow[b]{2}{*}{ Solvent } & \multicolumn{4}{|c|}{ Zone of inhibition (mm) } \\
\hline & & E. coli & $\begin{array}{l}S . \\
\text { aureus }\end{array}$ & $\begin{array}{l}P . \\
\text { aeruginosa }\end{array}$ & $\begin{array}{l}S . \\
\text { typhimurium }\end{array}$ \\
\hline $\begin{array}{l}\text { Calpurnia } \\
\text { aurea leaf }\end{array}$ & $\begin{array}{l}\text { Water } \\
\text { Acetone } \\
\text { Ethanol } \\
\text { Methanol }\end{array}$ & $\begin{array}{l}10.63 \pm 0.85^{\mathrm{ab}} \\
13.47 \pm 2.01^{\mathrm{cbd}} \\
11.24 \pm 1.18^{\mathrm{bca}} \\
14.59 \pm 0.72^{\mathrm{dc}}\end{array}$ & $\begin{array}{c}9.03 \pm 0.45^{\mathrm{ab}} \\
12.4 \pm 1.69^{\mathrm{cd}} \\
9.27 \pm 1.47^{\mathrm{ba}} \\
13.86 \pm 0.33^{\mathrm{dc}}\end{array}$ & $\begin{array}{c}8.78 \pm 1.82^{\mathrm{a}} \\
8.69 \pm 1.27^{\mathrm{a}} \\
8.72 \pm 0.2^{\mathrm{a}} \\
9.52 \pm 0.4^{\mathrm{a}}\end{array}$ & $\begin{array}{c}6.82 \pm 0.92^{\mathrm{a}} \\
9.15 \pm 1.01^{\mathrm{bc}} \\
11.07 \pm 0.89^{\mathrm{dc}} \\
9.57 \pm 0.68^{\mathrm{cbd}}\end{array}$ \\
\hline $\begin{array}{l}\text { Calpurnia } \\
\text { aurea } \text { Bark }\end{array}$ & $\begin{array}{l}\text { Water } \\
\text { Acetone } \\
\text { Ethanol } \\
\text { Methanol }\end{array}$ & $\begin{array}{c}7.29 \pm 1.61^{\mathrm{a}} \\
15.53 \pm 0.27^{\mathrm{bc}} \\
16.71 \pm 0.89^{\mathrm{cb}} \\
19.18 \pm 0.66^{\mathrm{d}}\end{array}$ & $\begin{array}{c}10.54 \pm 0.54^{\mathrm{a}} \\
17.4 \pm 1.46^{\mathrm{c}} \\
13.67 \pm 0.83^{\mathrm{b}} \\
22.64 \pm 0.95^{\mathrm{d}}\end{array}$ & $\begin{array}{c}9.16 \pm 0.72^{\mathrm{a}} \\
10.04 \pm 1.57^{\mathrm{bcd}} \\
11.95 \pm 1.1^{\mathrm{dbc}} \\
11.78 \pm 1.01^{\mathrm{cbd}}\end{array}$ & $\begin{array}{c}8.61 \pm 1.1^{5 \mathrm{ab}} \\
11.82 \pm 1.19^{\mathrm{ba}} \\
17.49 \pm 2.56^{\mathrm{dc}} \\
16.13 \pm 1.67^{\mathrm{cd}}\end{array}$ \\
\hline $\begin{array}{l}\text { Ocimum } \\
\text { lamiifolium } \\
\text { leaf }\end{array}$ & $\begin{array}{l}\text { Water } \\
\text { Acetone } \\
\text { Ethanol } \\
\text { Methanol }\end{array}$ & $\begin{array}{c}11.16 \pm 2.38^{\mathrm{ab}} \\
15.25 \pm 1.17^{\mathrm{dbc}} \\
13.57 \pm 1.17^{\mathrm{bcd}} \\
14.7 \pm 2.39^{\mathrm{cbd}}\end{array}$ & $\begin{array}{c}10.3 \pm 0.52 \mathrm{a} \\
13.8 \pm 1.49^{\mathrm{dc}} \\
12.77 \pm 1.52^{\mathrm{bc}} \\
13.2 \pm 3.2^{\mathrm{cdb}}\end{array}$ & $\begin{array}{l}7.96 \pm 3.53^{\mathrm{abc}} \\
8.05 \pm 1.29^{\mathrm{bcd}} \\
8.91 \pm 1.01^{\mathrm{cbd}} \\
10.63 \pm 0.54^{\mathrm{d}}\end{array}$ & $\begin{array}{r}8.51 \pm 1.52^{\mathrm{ab}} \\
8.53 \pm 0.74^{\mathrm{ba}} \\
10.4 \pm 2.27^{\mathrm{cd}} \\
11.84 \pm 0.74^{\mathrm{dc}}\end{array}$ \\
\hline $\begin{array}{l}\text { Ocimum } \\
\text { lamiifolium } \\
\text { Flower }\end{array}$ & $\begin{array}{l}\text { Water } \\
\text { Acetone } \\
\text { Ethanol } \\
\text { Methanol }\end{array}$ & $\begin{array}{c}7.86 \pm 0.4^{\mathrm{a}} \\
13.17 \pm 0.78^{\mathrm{cdb}} \\
13.02 \pm 0.4^{\mathrm{bcd}} \\
13.91 \pm 2.2^{\mathrm{dbc}}\end{array}$ & $\begin{array}{c}7.13 \pm 0.86^{\mathrm{a}} \\
12.42 \pm 1.76^{\mathrm{cbd}} \\
10.41 \pm 1.64^{\mathrm{bcd}} \\
12.85 \pm 0.64^{\mathrm{dbc}}\end{array}$ & $\begin{array}{c}6.12 \pm 0.41^{\mathrm{abc}} \\
7.82 \pm 0.61^{\mathrm{bacd}} \\
8.03 \pm 1.54^{\mathrm{cbad}} \\
9.42 \pm 0.76^{\mathrm{dbc}}\end{array}$ & $\begin{array}{c}8.21 \pm 0.98^{\mathrm{bac}} \\
8.16 \pm 1.64^{\mathrm{abc}} \\
9.86 \pm 179^{\mathrm{cab}} \\
10.39 \pm 0.83^{\mathrm{dc}}\end{array}$ \\
\hline $\begin{array}{l}\text { Ciprofloxaci } \\
\text { Solvent(-ve }\end{array}$ & $\begin{array}{l}\text { (+ve control) } \\
\text { ontrol) }\end{array}$ & $\begin{array}{c}26.15 \pm 0.38 \\
\text { na }\end{array}$ & $\begin{array}{c}24.00 \pm 0.19 \\
\text { na }\end{array}$ & $\begin{array}{c}27.70 \pm 0.45 \\
\text { na }\end{array}$ & $\begin{array}{l}26.83 \pm 0.27 \\
\text { na }\end{array}$ \\
\hline
\end{tabular}

In the case of the leaf solvent extract of Calpurnia aurea the methanol extract had the highest $(11.89 \mathrm{~mm})$ antibacterial activity against all tested bacteria and significantly different $(\mathrm{p}<0.05)$ from the acetone $(10.93 \mathrm{~mm})$, ethanol $(10.08 \mathrm{~mm})$ and water $(7.72 \mathrm{~mm})$ crude extract of Calpurnia aurea leaf. There was no significance difference $(\mathrm{p}>0.05)$ among acetone $(10.93 \mathrm{~mm})$ and ethanol $(10.08$ $\mathrm{mm})$ crude extract of Calpurnia aurea leaf but significantly different $(\mathrm{p}<0.05)$ from water $(7.72 \mathrm{~mm})$ and methanol $(11.89 \mathrm{~mm})$ crude extract in their zone of inhibition against all tested bacteria. The least zone of inhibition $(7.72 \mathrm{~mm})$ was observed from water crude extract of Calpurnia aurea leaf against all tested bacteria. Comparison between Calpurnia aurea leaf with different solvents shows that the methanol extract of Calpurnia aurea leaf was effective to treat those tested bacteria (Table 3). 
Table 3. Plant parts by extraction solvent interaction effect on antibacterial activity of Calpurnia aurea

\begin{tabular}{lllrrr}
\hline & & & $95 \%$ Confidence Interval for Mean \\
\hline Plant Part & Solvent & Mean & $\begin{array}{c}\text { Std. } \\
\text { Error }\end{array}$ & $\begin{array}{c}\text { Lower } \\
\text { Bound }\end{array}$ & $\begin{array}{r}\text { Upper } \\
\text { Bound }\end{array}$ \\
\hline Calpurnia aurea & Water & $8.90^{\mathrm{a}}$ & 0.44 & 7.93 & 9.88 \\
Bark & Acetone & $13.70^{\mathrm{b}}$ & 0.93 & 11.65 & 15.75 \\
& Ethanol & $14.12^{\mathrm{c}}$ & 0.71 & 12.56 & 5.68 \\
& Methanol & $17.19^{\mathrm{d}}$ & 1.14 & 14.67 & 19.71 \\
Calpurnia aurea & Water & $7.72^{\mathrm{a}}$ & 0.45 & 6.73 & 8.71 \\
Leaf & Acetone & $10.93^{\mathrm{bc}}$ & 0.73 & 9.33 & 12.53 \\
& Ethanol & $10.08^{\mathrm{cb}}$ & 0.42 & 9.16 & 11.00 \\
& Methanol & $11.89^{\mathrm{d}}$ & 0.72 & 10.30 & 13.48 \\
\hline
\end{tabular}

Mean values in the column that bear different superscript letters are significantly different at $(\mathrm{P}<0.05)$.

Regarding Ocimum lamiifolium flower, there was a significant difference $(\mathrm{p}<0.05)$ in antibacterial activities among the crude extracts of the two plant parts. Starting from Ocimum lamiifolium flower the crude extracts with methanol as a solvent showed the highest $(12.64 \mathrm{~mm})$ inhibition zone against all tested bacteria and significantly different $(\mathrm{p}<0.05)$ from three solvents acetone $(10.40 \mathrm{~mm})$, ethanol $(9.92 \mathrm{~mm})$ and water $(7.46 \mathrm{~mm})$, in their zone of inhibition against all tested bacteria. Also, there was no significant difference $(\mathrm{P}>0.05)$ among acetone and ethanol crude extract of Ocimum lamiifolium flower and had better antibacterial activity than that of water which had a least $(7.46 \mathrm{~mm})$ zone of inhibition. Comparing among Ocimum lamiifolium flower with different solvents, the methanol extract of Ocimum lamiifolium flower was effective to treat those tested bacteria (Table 4).

In the case of the leaf solvent extract of Ocimum lamiifolium, the methanol extract showed the highest zone of inhibition $(12.60 \mathrm{~mm})$ against all tested bacteria and significantly different $(\mathrm{p}<0.05)$ from ethanol $(10.42 \mathrm{~mm})$ and water $(7.46 \mathrm{~mm})$ crude extracts. The lowest zone of inhibition $(7.74 \mathrm{~mm})$ was observed from water extract. Comparison among Ocimum lamiifolium leaf extract with different solvents, show that the methanol and acetone extract of Ocimum lamiifolium leaf was effective to treat those tested bacteria (Table 4). 
Table 4. Plant parts by extraction with solvent interaction effect on antibacterial activity of Ocimum lamiifolium

\begin{tabular}{lllrrr}
\hline Plant part & Solvent & Mean & $\begin{array}{l}\text { Standard } \\
\text { error }\end{array}$ & \multicolumn{2}{c}{$\begin{array}{c}\text { 95\% confidence } \\
\text { interval }\end{array}$} \\
\cline { 5 - 6 } & & & & Lower & Upper \\
\hline Ocimum & Water & $7.74^{\mathrm{a}}$ & 0.67 & 6.26 & 9.21 \\
lamiifolium leaf & Acetone & $11.41^{\mathrm{cbd}}$ & 1.00 & 9.22 & 13.61 \\
& Ethanol & $10.42^{\mathrm{bc}}$ & 0.51 & 9.28 & 11.55 \\
& Methanol & $12.60^{\mathrm{dc}}$ & 0.68 & 11.09 & 14.10 \\
& & & & & \\
Ocimum & Water & $7.46^{\mathrm{a}}$ & 0.27 & 6.86 & 8.06 \\
lamiifolium & Acetone & $10.40^{\mathrm{cb}}$ & 0.80 & 8.64 & 12.15 \\
flower & Ethanol & $9.92^{\mathrm{bc}}$ & 0.51 & 8.80 & 11.04 \\
& Methanol & $12.64^{\mathrm{d}}$ & 0.63 & 10.26 & 13.03 \\
\hline
\end{tabular}

Mean values in the column that bear different superscript letters are significantly different at $(\mathrm{P}<0.05)$.

Among all tested plant parts Calpurnia aurea (bark and leaf) and Ocimum lamiifolium (leaf and flower), Calpurnia bark had a better antibacterial activity $(13.48 \mathrm{~mm})$ and significantly different $(\mathrm{p}<0.05)$ from Calpurnia aurea leaf $(10.15$ $\mathrm{mm})$, Ocimum lamiifolium leaf $(10.54 \mathrm{~mm})$ and Ocimum lamiifolium flower $(9.86$ $\mathrm{mm})$ against all tested bacteria. Also, there is no significance difference $(\mathrm{p}>0.05)$ among Ocimum lamiifolium leaf $(10.15 \mathrm{~mm})$, Ocimum lamiifolium flower $(9.86$ $\mathrm{mm})$ and Calpurnia aurea leaf $(10.15 \mathrm{~mm})$ in their zone of inhibition. This result indicated that Calpurnia aurea bark had high anti-bacterial activity than the others against tested bacteria (Table 5).

\section{Minimum inhibitory Concentration (MIC)}

The MIC assay was also employed to evaluate the effectiveness of the extracts to inhibit the growth of the tested bacteria. In the current study the MIC of water extracts of all tested plant parts were between $100-200 \mathrm{mg} / \mathrm{ml}$ against all tested bacteria. The MIC of acetone extract of Calpurnia aurea leaf $(25 \mathrm{mg} / \mathrm{ml})$ inhibited E. coli and $S$. aureus. In this case ethanol extract $(25 \mathrm{mg} / \mathrm{ml})$ inhibited $E$. coli and $50 \mathrm{mg} / \mathrm{ml}$ inhibited $S$. aureus and S. typhimurium.

Among methanol crude extracts of Calpurnia aurea leaf the MIC was $12.5 \mathrm{mg} / \mathrm{ml}$ which inhibited $E$. coli and $25 \mathrm{mg} / \mathrm{ml}$ inhibited $S$. aureus. The MIC value of methanol extract of Calpurnia aurea leaf against $S$. aureus was $25 \mathrm{mg} / \mathrm{ml}$ which was agreed with the result of Hailu et al. (2005) in which the MIC value of $25 \mathrm{mg} / \mathrm{ml}$ inhibited $S$. aureus. Also, a comparable result was observed from Shemsu et al. (2013) in which $62.5 \mathrm{mg} / \mathrm{ml}$ inhibited S. typhimurium. 
Table 5. Plant parts of Calpurnia aurea and Ocimum lamiifolium interaction with bacterial species.

\begin{tabular}{lccrr}
\hline Plant part & Mean & $\begin{array}{c}\text { Standard } \\
\text { error }\end{array}$ & \multicolumn{2}{c}{$\mathbf{9 5 \%}$ Confidence Interval } \\
\cline { 4 - 5 } & & & Lower & Upper \\
\hline Calpurnia aurea Leaf & $10.15^{\text {bac }}$ & 0.37 & 9.42 & 10.89 \\
Calpurnia aurea Bark & $13.48^{\mathrm{d}}$ & 0.60 & 12.28 & 14.68 \\
Ocimum lamiifolium Leaf & $10.54^{\text {cab }}$ & 0.44 & 9.65 & 11.43 \\
Ocimum lamiifolium Flower & $9.86^{\text {abc }}$ & 0.36 & 9.13 & 10.58 \\
\hline
\end{tabular}

Mean values in the column that bear different superscript letters are significantly different at $(\mathrm{P}<0.05)$.

In the case of acetone crude extract of Calpurnia aurea bark $12.5 \mathrm{mg} / \mathrm{ml}, 25 \mathrm{mg} / \mathrm{ml}$ and $50 \mathrm{mg} / \mathrm{ml}$ inhibited $S$. aureas, E. coli and $S$. typhimurium respectively. Among ethanol crude extracts of Calpurnia aurea bark $6.25 \mathrm{mg} / \mathrm{ml}$ inhibited $S$. typhimurium, $25 \mathrm{mg} / \mathrm{ml}$ inhibited $E$. coli and $50 \mathrm{mg} / \mathrm{ml}$ inhibited $S$. aureus. The MIC of methanol crude extract of Calpurnia bark was $3.12 \mathrm{mg} / \mathrm{ml}$ that inhibited $S$. aureus which had a potential to treat disease of $S$. aureus, also $6.25 \mathrm{mg} / \mathrm{ml}$ inhibited E. coli and $12.5 \mathrm{mg} / \mathrm{ml}$ inhibited S. typhimurium (Table 6).

The MIC of acetone crude extract of Ocimum lamiifolium leaf was $25 \mathrm{mg} / \mathrm{ml}$ which inhibited $E$. coli followed by $50 \mathrm{mg} / \mathrm{ml}$ inhibited $S$. aureus. MIC of ethanol crude extract of Ocimum lamiifolium leaf $(50 \mathrm{mg} / \mathrm{ml})$ inhibited E. coli, $S$. aureus and $S$. typhimurium respectively. In case of Ocimum lamiifolium leaf methanol crude extract $25 \mathrm{mg} / \mathrm{ml}$ inhibited $E$. coli and $50 \mathrm{mg} / \mathrm{ml}$ crude extract inhibited $S$. aureus, $P$. aeruginosa and $S$. typhimurium. The MIC of Water crude extract of Ocimum lamiifolium leaf which inhibited $S$. aureus at $200 \mathrm{mg} / \mathrm{ml}$, also, inhibited E. coli and $P$. aeruginosa at $100 \mathrm{mg} / \mathrm{ml}$. A comparable report observed from Amare et al. (2013) $200 \mathrm{mg} / \mathrm{ml}$ inhibited $S$. aureus, as well as $100 \mathrm{mg} / \mathrm{ml}$ inhibited $E$. coli and $P$. aeruginosa. The MIC of acetone crude extract of Ocimum lamiifolium flower (50 $\mathrm{mg} / \mathrm{ml}$ ) inhibited $E$. coli and $S$. aureus. Methanol extract of Ocimum lamiifolium flower inhibited E. coli at $25 \mathrm{mg} / \mathrm{ml}$ and also inhibits $S$. aureus and S. typhimurium at $50 \mathrm{mg} / \mathrm{ml}$. The MIC of Ethanol crude extract of Ocimum lamiifolium flower inhibited E. coli at $50 \mathrm{mg} / \mathrm{ml}$ (Table 6).

Tested plant parts which were extracted with different solvents showed different MIC. The methanol crude extract of Calpurnia aurea leaf had a potential to inhibit $E$. coli at $6.25 \mathrm{mg} / \mathrm{ml} \mathrm{so}$, it had a potential to treat E. coli. Also, the methanol crude extract of Calpurnia aurea bark had a potential to inhibit $S$. aureus at $3.12 \mathrm{mg} / \mathrm{ml}$, so it has a potential to treat of these bacteria. The ethanol crude extract of Calpurnia aurea bark had a potential to inhibit $S$. typhimurium at $6.25 \mathrm{mg} / \mathrm{ml}$; so, it has a potential to treat $S$. typhimurium (Table 6). 
Table 6. Minimum inhibitory concentrations $(\mathrm{mg} / \mathrm{ml})$ of $C$. aurea (leaf, bark) and $O$. lamiifolium (leaf, flower) in four different extraction solvents

\begin{tabular}{llcccc}
\hline Plant parts & Extraction & \multicolumn{3}{c}{ Bacteria species } \\
\cline { 3 - 5 } & solvent & $\boldsymbol{E}$. & $\boldsymbol{S}$. & $\boldsymbol{P}$. & S. \\
& & coli & aureus & aeruginosa & typhimurium \\
\hline C. aurea Leaf & Water & 200 & 100 & 200 & 200 \\
& Acetone & 25 & 25 & 100 & 50 \\
& Ethanol & 25 & 50 & 100 & 50 \\
& Methanol & 12.5 & 25 & 100 & 50 \\
C. aurea Bark & Water & 100 & 100 & 100 & 100 \\
& Acetone & 25 & 12.5 & 100 & 50 \\
& Ethanol & 25 & 50 & 100 & 6.25 \\
& Methanol & 6.25 & 3.12 & 50 & 12.5 \\
O. lamiifolium & Water & 100 & 200 & 100 & 100 \\
& Acetone & 25 & 50 & 100 & 100 \\
& Ethanol & 50 & 50 & 100 & 50 \\
& Methanol & 25 & 50 & 50 & 50 \\
O. lamiifolium & Water & 200 & 200 & 200 & 200 \\
Flower & Acetone & 50 & 50 & 100 & 100 \\
& Ethanol & 50 & 100 & 200 & 100 \\
& Methanol & 25 & 50 & 100 & 50 \\
\hline
\end{tabular}

\section{CONCLUSION}

In conclusion, the demonstrated antimicrobial activities of the crude extracts of the four plant parts Calpurina aurea (leaf and bark) and Ocimum lamiifolium (leaf and flower) with 4 different solvents; methanol, acetone, ethanol and water have given a preface of their potentials as antimicrobial agents. Among the parts of the plants included in the current study, the barks of Calpurnia aurea were found to be the best source of antibacterial agents. Likewise, among the extraction solvents employed for the current study, $80 \%$ methanol was found to be the best extraction solvent. This shows the potential of the plants for developing drugs for treating various illnesses in human beings and Animals. The susceptibility of the four bacteria species appeared to be influenced by the plant parts and the extraction solvent used. This result confirmed that extracts of medicinal plants showed a comparable result to standard antibiotics and validates the use of the studied plant parts in traditional medicine. 


\section{REFERENCES}

Abdella Gemechu, Mirutse Gidey, Worku Adane and Gobena Amen. (2013). In vitro antimycobacterial activity of selected medicinal plants against Mycobacterium tuberculosis and Mycobacterium bovis Strains. Biomed Central Complementary and Alternative Medicine 13: 291.

Abebe Dawit. (2011). The role of medicinal plants in healthcare coverage of Ethiopia, the possible integration. In: Conservation and Sustainable Use of Medicinal Plants in Ethiopia. Proceeding of The National Workshop on Biodiversity Conservation and Sustainable Use of Medicinal Plants in Ethiopia held from 28 April-01 May 1998, Pp. 621.

Aiyegoro, O., Adewusi, A., Oyedemi, S., Akinpelu, D and Okoh, A. (2011). Interactions of antibiotics and methanolic crude extracts of Afzelia africana (smith.) against drug resistance bacterial isolates. International Journal of Molecular Sciences 12(7): 477503.

Amare Gebrehiwot, Chandrashekhar and Unakal, G. (2013). Effect of aqueous and ethanol extracts of Ocimum lamiifolium and Amaranthus dubius against bacteria isolated from clinical specimen. International Journal of Pharmaceutical Research 03(01):10-14.

Anokwuru, C.P.1., Anyasor, G.N.1., Ajibaye, O., Fakoya, O.1 and Okebugwu, P. (2011). Effect of Extraction Solvents on Phenolic, Flavonoid and Antioxidant activities of Three Nigerian Medicinal Plants. Nature and Science 9:7.

Bacha Ketema, Tariku Yinebeb, Gebreyesus Fisseha, Zerihun Shibiru, Mohammed Ali, Weiland-Bräuer N Schmitz R.A and Mulat, M. (2016). Antimicrobial and anti-Quorum Sensing activities of selected medicinal plants of Ethiopia: Implication for development of potent antimicrobial drugs. Biomed Central Microbiology 16:139.

Bassetti, M., Ginocchio, F., Mikulska, M., Taramasso, L and Giacobbe, D.R. (2011). Will new antimicrobials overcome resistance among Gram-negatives? Expert Review of Antiinfective Therapy 9(10): 909-22.

Bhumika D and Bijal, A. (2015). Antibacterial activity and Phytochimical Screening of different parts of medicinal plant against selected gram positive and gram-negative bacteria. Journal of Pharmacology, Chemistry and Biological Science 3(3):421-425.

Binyam Adugna, Getachew Terefe, Nigatu Kebede, Wondu Mamo and Simenew Keskes. (2014). Potential Invitro Anti-Bacterial Action of Selected Medicinal Plants against Escherichia coli and Three Salmonella Species. International Journal of Microbiological Research 5(2): 85-89.

Canter, P.H., Thomas, W.H and Ernst, E. (2005). Bringing medicinal plants into cultivation: opportunities and challenges for biotechnology. Trends in Biotechnology 23:180-185.

Chenielle, D., Lois, R., Sylvia, N., John M and Mohammed, A. (2009). Antibacterial and antifungal analysis of crude extract from the leaves of Callistemon viminalis. Journal of Medical and Biological Science 3(1):1-7.

CLSI (Clinical and Laboratory Standards Institute). (2012). Methods for dilution antimicrobial susceptibility tests for bacteria that grow aerobically approved standard. 9thed. Wayne. Vol. 32: USA.

CSA (2013). Central statistical agency report on population of Ethiopia, 2013.

Ermiyas Dagne. (2009). Natural Data Base for Africa (NDA) on CD-ROM, Addis Ababa, Ethiopia. Specie ID 302. 
Gordon, M.C and David, J.N. (2001). Natural product during discovery in the next millennium. Pharmaceutical Biology 39: 8-17.

Hailu Tadeg, Endris Mohammed, Kaleb Asres and Tsige Gebre-Maria. (2005). Antimicrobial activities of some selected traditional Ethiopian medicinal plants used in the treatment of skin disorders. Journal of Ethnopharmacology 100: 168-175.

Handa, S.S., Khanuja, S.P.S., Longo, G and Rakesh D.D. (2008). Extraction technologies for medicinal and aromatic plants. Trieste 45:432-502.

Havagiray, R., Ramesh, C., Sadhna, K. (2004). Study of antidiarrhoeal activity of Calotropis gigantear.b.r. in experimental animals. Journal of Pharmacy and Pharmaceutical Sciences 7:70-75.

Kamatenesi, M and Oryem-Origa, H. (2007). Medicinal plants used to induce labor during childbirth in Western Uganda. Journal of Ethno pharmacology 109:1-9.

Kashyap, C.P., Ranjeet, K and Vipin, K. (2011). Therapeutic Potency of Ocimum kilim and scharicum Guerke-A Review. Global Journal of Pharmacology 5(3):191-200.

Khulbe, K and Sati, S.C. (2009). Antibacterial activity of Boenning hausenia albiflora Reichb. (Rutaceae). African Journal of Biotechnology 8:6346-6348.

Mirutse Giday, Zemede Asfaw and Zerihun Woldu. (2010). Ethnomedicinal study of plants used by Sheko ethnic group of Ethiopia. Journal of Ethnopharmacology 132: 75-85.

Miyakis, S., Pefanis, A and Tsakris, A. (2011). The challenges of antimicrobial drug resistance in Greece. Clinical Infectious Diseases 53(2):177-84.

Owolabi, M.A., Coker, H.A.B and Jaja, S.I. (2007). Flavonoid metabolites in urine after oral administration of the aqueous extract of Persea americana to rats. Journal of Natural Medicines 61:2004. https://doi.org/10.1007/s11418-006-0122-7

Perumal, S., Pillai, S., Lee, W.C., Mahmud, R. and Ramanathan, S. (2012). Determination of Minimum Inhibitory Concentration of Euphorbia hirta (L.) Extracts by Tetrazolium Microplate Assay. Journal of Natural Products 5: 68-76.

Radojevic, I., Stankovic, O., Topuzovic, M., Comic, L and Ostojic, A. (2012). Great Horsetail (Equisetum telmateiaEhrh.): Active Substances Content and Biological Effects. Experimental and Clinical Sciences International Journal 11: 59-67.

Shemsu Umer, Alemu Tekewe and Nigatu Kebede. (2013). (Antidiarrhoeal and antimicrobial activity of Calpurina aurea leaf extract Biomed Central Complementary and Alternative Medicine 13:21.

Sidama Zone Finance and Economic Development Department Statistical Abstract. (2014). Southern Nations, Nationalities \& People's Regional State Socio Economic profile of Sidama Zone.

Srinivasan, D., Perumalsamy, L.P., Nathan, S and Sures, T. (2001). Antimicrobial activity of certain Indian Medicinal Plants used in folkloric medicine. Journal of Ethnopharmacology 94:217-222.

Sukhdev, S.H., Sudeep, T., Sukhdev, S.H., Suman Preet, S.K., Gennaro, L and Dev, D.R. (2008). Extraction Technologies for medicinal and aromatic plants scientific. International Centre for Science and High Technology/United Nations Industrial Development Organization 1(2-7):40-126.

Tadeg, H., Mohammed, E., Asres, K., Gebre-Mariam, T. (2005). Antimicrobial activities of some selected traditional Ethiopian medicinal plants used in the treatment of skin disorders. Journal of Ethnopharmacology 100:168-175. 
Taiwo, S.S., Oyekanmi, B.A. Adesiji, Y.O. Opaleye, O.O. and Adeyeba, O.A. (2007). In vitro antimicrobial activity of crude extract of Citrus aurantifolia Linn. and Titonia diversifolia (Poaceae) on clinical bacterial isolates. International Journal of Tropical Medicine 2(4): 113 - 117.

Teklit Gebregiorgis Amabye and Said Mussa. (2015). In Vitro Antimicrobial Efficacy of Fractions from Demakese (Ocimum lamifolium) Leaves Extract from Mekelle Tigray, Ethiopia. Natural Products Chemistry and Research 3:. http://dx.doi.org/10.4172/23296836.1000196

Tesema Tesfaye, Mirutse Gidey and Nigusu Asefa. (2002). National Biodiversity Strategy and Action Plan Project. Resource base of medicinal plants of Ethiopia, first phase report, Addis Ababa, Ethiopia.

WHO. (2011). World Malaria Report. World Health Organization, Geneva.

Zorloni, A. (2007). Evaluation of plants used for the control of animal ectoparasites in southern Ethiopia (Oromiya and Somalia regions). MSc Thesis, University of Pretoria. 